\title{
Has expansion of mobile phone and internet use spurred financial inclusion in the SAARC countries?
}

\author{
Sanjaya Kumar Lenka ${ }^{*}$ and Rajesh Barik²
}

\author{
* Correspondence: sanjaya. \\ iitindore19@gmail.com \\ ${ }^{1}$ Consumer Unity \& Trust Society \\ (CUTS) International (a global \\ independent non-profit economic \\ policy research and advocacy \\ organization), D-217, Bhaskar Marg, \\ Bani Park, Jaipur, Rajasthan -302016, \\ India \\ Full list of author information is \\ available at the end of the article
}

\begin{abstract}
Exclusion from the mainstream financial world is a burden on the poor of many countries. The proliferation of new mobile and online financial services, such as e-banking, money transfers, and payment processing has the potential to provide access to basic financial products and services to financially excluded people. The purpose of this study was to investigate the effects of the growth of mobile phone and Internet use on financial inclusion in the South Asian Association for Regional Cooperation (SAARC) countries from 2004 to 2014. We applied principal component analysis to construct a financial inclusion index that served as a proxy variable for the accessibility of financial services in the SAARC countries. Using three different models-the fixed effect, random effect, and panel correction standard errors modelsthis study discovered a positive and significant relationship between the growth of financial inclusion and expansion of both mobile phone and Internet services. Moreover, an empirical study of the control variables showed that the levels of income and education were positively associated with financial inclusion, whereas the size of the rural population and unemployment were negatively related to financial inclusion. In addition, the empirical estimates posit a unidirectional causal flow from the growth of mobile and Internet services to expanded financial inclusion in the SAARC countries.
\end{abstract}

Keywords: Financial inclusion, Fixed effect, Random effect, Panel corrected standard errors, SAARC

JEL classifications: B26, F36, F38, G2F

\section{Introduction}

Financial inclusion is one of the unspoken key drivers for building an inclusive society and inclusive economy. In recent times, member countries of the South Asian Association for Regional Cooperation (SAARC) have paid considerable attention to promoting financial inclusion in their respective nations. The levels of financial inclusion and development vary widely among the SAARC countries. Until recently, for vast numbers of people, formal financial products and services have been out of reach.

Financial exclusion is caused by demand factors as well as supply factors. Accordingly, to speed up the drive toward greater financial inclusion, initiatives must be taken from both the demand and supply sides. Focusing on supply-side factors alone will not solve the problem of financial exclusion. However, efforts to promote financial inclusion have

(c) The Author(s). 2018 Open Access This article is distributed under the terms of the Creative Commons Attribution 4.0 International License (http://creativecommons.org/licenses/by/4.0/), which permits unrestricted use, distribution, and reproduction in any medium, provided you give appropriate credit to the original author(s) and the source, provide a link to the Creative Commons license, and indicate if changes were made. 
been adopted primarily from the supply side, including nationalization of banks, an extension of bank branches to rural areas, provision of credit to previously excluded sectors, and adjustment of loan interest rates for low-income households. The development of mobile financial service providers such as bKash Limited (a subsidiary of BRAC Bank) and Dutch Bangla Bank mobile services in Bangladesh, and the expansion of branchless banking and mobile banking in Pakistan, are among the more recent initiatives taken by individual SAARC countries to increase the speed of financial inclusion.

Utilization of mobile phones and the Internet to provide financial services has become a new way to offer unbanked people more opportunities to participate in the formal financial system. Mobile money services have increased the access of rural people to financial products and services at a reasonable cost (Thulani et al. 2014). E-banking with a well-developed banking infrastructure provides many secure and convenient services, including 24/7 banking, bill paying, online deposits, money transfers between individuals and between banks, on-time message delivery, around-the-clock call centers, and purchase of airline or train tickets.

E-banking is effective in reducing transaction costs. The ability to conduct financial transactions anytime, anywhere using a personal computer or mobile device saves both time and money by eliminating the need to visit a physical bank branch. Banks have worked to build consumer confidence that e-banking is as convenient and reliable as banking in person. Alam et al. (2013) found that mobile banking is more convenient, affordable, and secure. E-financial services increase the banking habits of customers as well. Liao and Cheung (2002) also found that a well-developed, user-friendly banking infrastructure provides customers with such advantages as greater accuracy, reliability, security, convenience, and speed of transactions.

The use of mobile banking and Internet banking is quite popular in African countries. Examples include Celpay Zambia Limited's mobile payments solutions, as well as WIZZIT mobile banking solutions and MTN mobile telecommunications in South Africa. In Kenya, through M-PESA's mobile financial services, people are entering into a new kind of social structure in which mobile banking plays an important role. M-PESA has proven successful in connecting a large number of previously unbanked and underbanked people in Kenya with the financial system. Kusimba et al. (2013) concluded that the availability of mobile money solutions created a new form of value in Kenyan lives by providing the means for easy transfer of money to friends, relatives, and family members. This facility provides new avenues for social relationships and supports networks with loved ones. For small-scale businessmen and traders, mobile and Internet banking are helpful for conducting daily business transactions.

Similarly, a few of the SAARC countries have made efforts to extend the drive toward financial inclusion. The introduction of the eZ Cash mobile financial service by the Central Bank of Sri Lanka in 2012 is one significant initiative that widened the boundaries of financial inclusion. This mobile money service has the dual objectives of financial inclusion and economic growth. eZ Cash has covered many unbanked citizens, and it has opened new market opportunities for both banking and non-banking institutions. In Pakistan, the launching of Easypaisa mobile financial services in 2009 was a major initiative for faster financial inclusion. The primary emphasis of this service is to extend mobile banking accounts, create consciousness about mobile banking, and spread information regarding the benefits of mobile banking. In India, the development of Airtel 
Money and EKO India Financial Services has covered a large number of previously non-banked customers, spreading the boundaries of financial inclusion.

Currently, many developing countries are working to include financially excluded people in the mainstream formal financial system through the use of mobile banking and Internet banking. In each SAARC country, the number of mobile users is greater than the number of people in the banking population. There is enormous room for banks to extend their banking services through mobile banking to the unbanked population. The extension of mobile and Internet banking to unbanked/under-banked regions and citizens is a means through which all SAARC countries could fulfill the dream of financial inclusion successfully.

To fulfill this dream of financial inclusion, in 1969 the Government of India (GOI) nationalized fourteen banks. The objective was to increase the savings and access to credit of low-income people and to extend banking services to less developed financial regions (Hirashima et al. 2011). In 1980, six more banks were nationalized to expand the range of financial inclusion in India. For the expansion of bank branches in the rural unbanked regions, the Central Bank of India declared a branch licensing policy in 1977. The Central Bank governors argued that through the bank licensing policy, the expansion of bank branches to rural areas or the unbanked regions from 1977 to 1990 had a significant effect on poverty reduction (Burgess and Pande 2005).

In India today, financial inclusion for every individual is seen as a necessary precondition for inclusive development (Sangmi 2013). Unfortunately, because of leakage and corruption high in the government distribution system, many resources are unable to reach the poorest of the poor. As a remedy, for some of the services, the GOI has implemented a direct cash transfer system for transferring money directly to the beneficiaries' bank accounts. It has been argued that payment of government subsidies through bank accounts and the post office will have less leakage. In this regard, mobile phones and the Internet play a vital role in helping the government fulfill this program successfully. Moreover, mobile payments can eradicate corruption from the system by achieving greater distribution.

In addition to financial inclusion, many government departments are providing mobile services to citizens for the purpose of good governance. Using mobile phones, the people can gather all kinds of government information or file complaints in case of any government irregularities. This access will help to better the welfare of the citizens. In addition, the advancement of information and communication technology spurs economic growth by making the market more efficient, which ultimately generates more income for the poor and reduces poverty in the economy.

The remainder of this paper is structured as follows. In Section 2, we examine the status of mobile and Internet services in SAARC countries from 2004 to 2014. Section 3 provides an overview of related research. In Section 4, we provide a statement of the contributions of this study, and in Section 5 we detail our methodology. Section 6 gives our results and provides a discussion. Section 7 provides our conclusion and policy implications.

Status of mobile and internet services in SAARC countries from 2004 to 2014

Cherotich et al. (2013) argued that the introduction of new technology in the banking system in Kenya completely altered the banking philosophy. These innovative methods 
provided a strategic approach to the achievement of high profitability, efficiency, and productivity among Kenya's commercial banks. In India, the Planning Commission of the GOI (2009) advised that mobile and Internet banking in India, and the associated reduction in transaction costs, had proved to be the most prominent innovation in the banking industry to facilitate financial inclusion, especially among individual customers. This position was supported by Rajeev and Vani (2017) and Vadavadagi and Allagi (2014). Similarly, Sultana and Khan (2016) found that mobile financial services in Bangladesh were gaining high popularity as a result of the initiatives taken by the Bank of Bangladesh.

In addition to providing mobile money services, different SAARC countries have undertaken other supplementary initiatives to speed up the move toward financial inclusion. For example, some SAARC members have introduced awareness and initiated financial literacy and education programs to provide individuals with expertise in handling new technologies introduced by the banking systems. Through the help of the South Asian Federation of Exchange (SAFE), a financial literacy initiative program was introduced in Pakistan to increase the level of financial inclusion. Similarly, other SAARC countries such as India, Bangladesh, and Sri Lanka have undertaken key initiatives to introduce financial literacy to their citizens.

Table 1 shows selected economic indicators in SAARC countries from 2004 to 2014. The table shows that the number of mobile and Internet users increased across all the SAARC countries over the period indicated. The countries with higher per capita income used more mobile and Internet services. Separately, Fig. 1 shows the status of mobile phone and Internet usage in SAARC countries.

Internet and mobile services have been essential determinants for extending the drive toward financial inclusion. Across all the SAARC countries most of the financial transactions occur through Internet banking and mobile banking, both of which have become increasingly popular choices over the past decade, especially among younger adults, as a result of the introduction of iPhones and Android handsets. Although the number of both mobile users and Internet users increased rapidly, there was a greater percentage of mobile users compared with Internet users in all SAARC countries from 2004 to 2014. Among all the SAARC countries, Maldives ranked at the top for both mobile users and Internet service users. In the case of mobile users, Sri Lanka placed second, whereas Bhutan was second in Internet service users among SAARC countries. The percentage of mobile users in all other countries respectively (India, Bangladesh, Pakistan, Afghanistan, Nepal, and Bhutan) was about the same (around 73-82\%). Afghanistan ranked last in terms of Internet users (Fig. 1).

\section{Literature review}

The concept of financial inclusion through mobile and Internet banking is not new. Although research regarding financial inclusion through mobile and Internet banking in African countries has been reasonably extensive, the literature has not been equally thorough in addressing financial inclusion in the context of SAARC countries. Moreover, most the studies focused on e-banking or mobile banking have been descriptive in nature. Some of the studies that have conducted empirical analysis in African and Asian countries are listed in Table 2. 


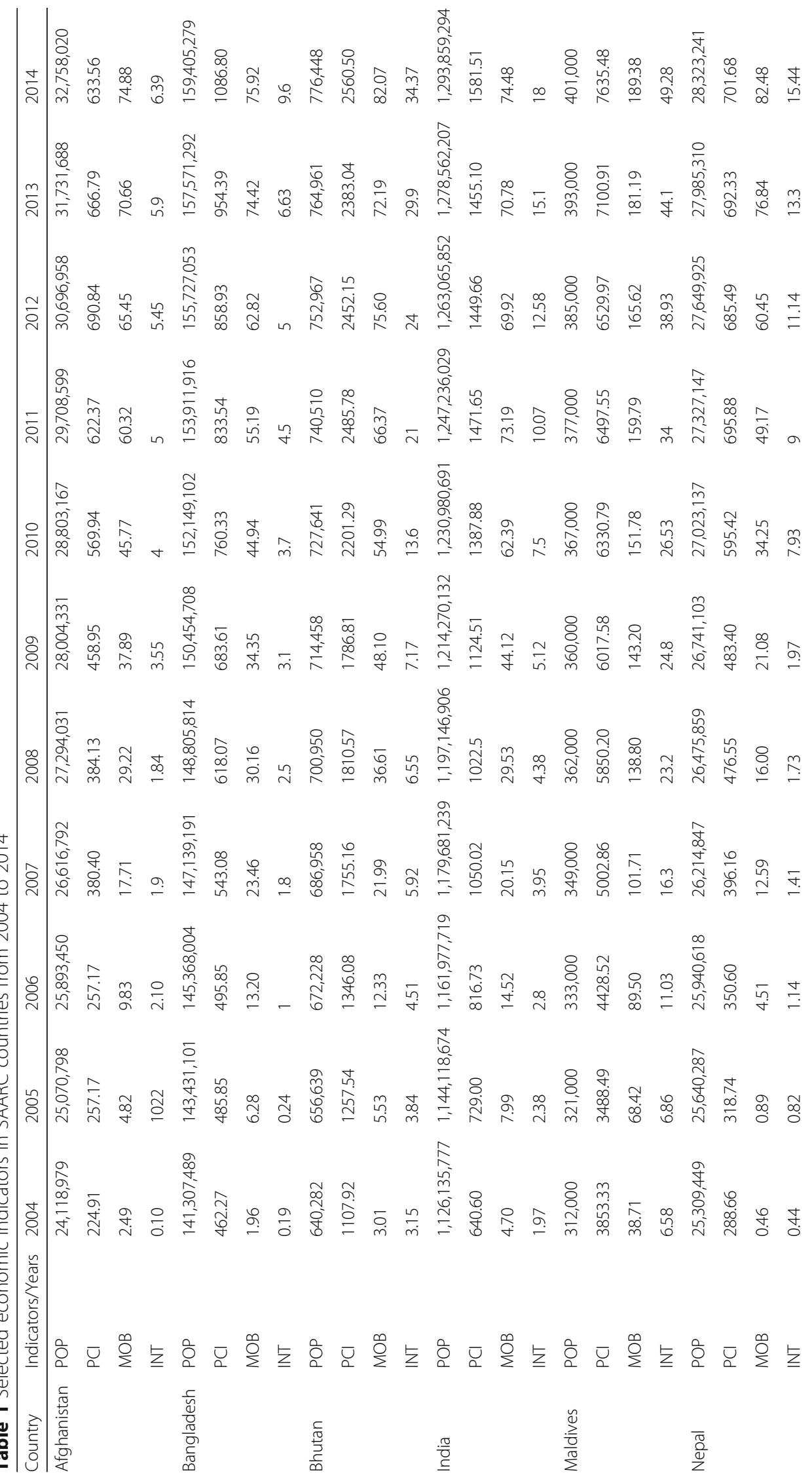




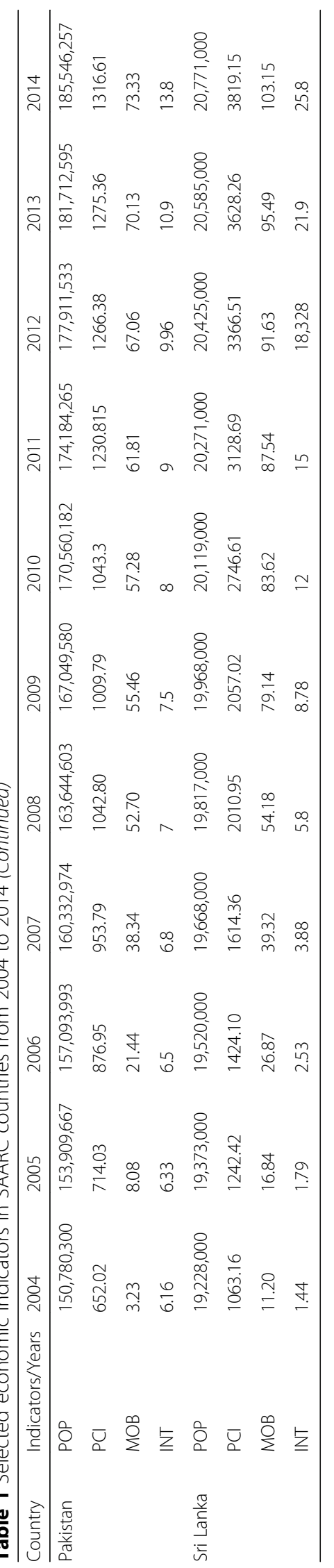



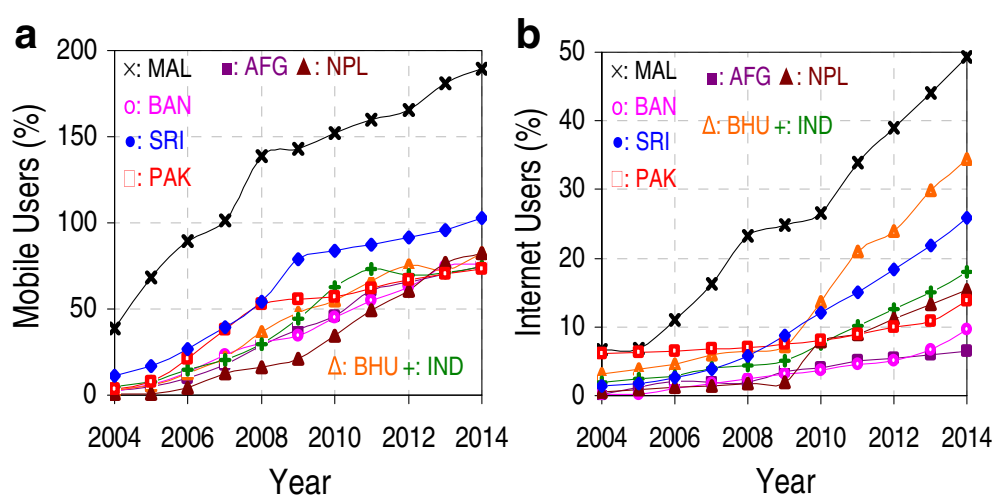

Fig. 1 Mobile and Internet services in SAARC countries

As mentioned previously, both mobile and Internet banking help to build an inclusive financial system in a country by providing an easy way to access banking products and services. In addition, there is clear evidence that the wide use of mobile phones spurs economic growth through financial inclusion. Andrianaivo and Kpodar (2012) found mobile phone penetration has a positive impact on economic growth. Moreover, independently, the correlation between mobile phone penetration rates and financial inclusion was found to be positive and significant. Ghosh (2016) conducted a study in 14 major states in India and found that the penetration of mobile telephones had a positive and significant effect on the states' economic growth as well as a positive impact on financial inclusion.

Mago and Chitokwindo (2014) conducted a qualitative survey in Masvingo district in Zimbabwe and found that economically disadvantaged people in Zimbabwe have adopted mobile banking because it is easily accessible, fast, cheap, and secure. Ouma et al. (2017) conducted a study in a few selected countries in Sub-Saharan Africa. They found that use of mobile telephones increases saving among povertylevel and low-income households. This increment of deposits and savings was a

Table 2 Empirical study conducted in African and Asian countries with regard to mobile and Internet banking

\begin{tabular}{|c|c|c|c|}
\hline Author (s) & County & $\begin{array}{l}\text { Data } \\
\text { Sources }\end{array}$ & Findings \\
\hline Ouma et al. (2017) & $\begin{array}{l}\text { Sub- } \\
\text { Saharan } \\
\text { Africa }\end{array}$ & $\begin{array}{l}\text { Secondary } \\
\text { Data }\end{array}$ & $\begin{array}{l}\text { Mobile financial services boost saving habits among the poor } \\
\text { and low-income households. }\end{array}$ \\
\hline Siddik et al. (2017) & Bangladesh & $\begin{array}{l}\text { Secondary } \\
\text { Data }\end{array}$ & E-banking improves the performance of banks. \\
\hline $\begin{array}{l}\text { Andrianaivo and } \\
\text { Kpodar (2012) }\end{array}$ & $\begin{array}{l}\text { African } \\
\text { Countries }\end{array}$ & $\begin{array}{l}\text { Secondary } \\
\text { Data }\end{array}$ & $\begin{array}{l}\text { Mobile phone use spurs economic growth through financial } \\
\text { inclusion. }\end{array}$ \\
\hline Aker (2010) & Niger & $\begin{array}{l}\text { Primary } \\
\text { Data }\end{array}$ & $\begin{array}{l}\text { The use of mobile phone services has reduced grain price } \\
\text { dispersion. }\end{array}$ \\
\hline $\begin{array}{l}\text { Aker and Mbiti } \\
(2010)\end{array}$ & Africa & $\begin{array}{l}\text { Secondary } \\
\text { Data }\end{array}$ & The use of mobile phones promotes economic development. \\
\hline Ghosh (2016) & $\begin{array}{l}\text { Indian } \\
\text { States }\end{array}$ & $\begin{array}{l}\text { Secondary } \\
\text { Data }\end{array}$ & $\begin{array}{l}\text { Mobile phone use has a positive and significant impact on state } \\
\text { economic growth and financial inclusion. }\end{array}$ \\
\hline
\end{tabular}

Source: Prepared by authors 
sign of increased financial inclusion, which ultimately has a positive impact on the financial health of the country.

Similarly, Siddik et al. (2016) conducted a study in Bangladesh using panel data of 13 banks over the period from 2003 to 2013. Their study found that e-banking had a positive impact on the performance of the banks, and e-banking played a crucial role in accelerating the growth of the economy. These findings suggest that the level of mobile banking usage can affect the financial policy formulation of developing countries. In addition to affecting financial regulatory policy in developing and emerging countries, the use of mobile phones also provides insight into the main reasons for market failure and points to the regulatory steps needed for correction (Klein and Mayer 2011).

Furthermore, researchers considered that use of mobile phones and the Internet establishes a good social network among individuals. Based on empirical research, Aker and Mbiti (2010) found evidence that both consumers and producers can benefit from the use of mobile phones and the Internet. Fuller economic development is promoted as well. Consumers can know the exact price of a product by comparing all prices, and producers can conduct business in new markets and set up new business networks. In rural India, there is a wide variation in the prices of agricultural products because asymmetric information exists in the market. Both traders and consumers find it time to consume to gather exact prices for a variety of agricultural products. The use of mobile phones allows them to compare prices in a shorter amount of time and at a minimum cost. The spread of mobile phones has narrowed down the information gap for agricultural products and has helped to increase the welfare of both consumers and sellers by reducing their search cost. The evidence showed that the widespread coverage of mobile phones across the market reduced price dispersion (Aker 2010).

The advantage of using mobile phones was analyzed in relation to the fishing industry in India as well. Research demonstrated that the widespread use of mobile phones by the fishermen helped them to keep contact with their family members, relatives, and friends. Mobile phones allowed the fishermen to be aware of current prices and to gather all of the information related to the demand for fish in the market. The far-flung use of mobile phones reduced the risks and uncertainties of the market while increasing efficiency and productivity (Abraham 2007).

Recent developments in information and communication technology have smoothed the way for market players to function efficiently. In particular, the greater availability of information encourages even the small and marginalized market players to participate in the market. Eggleston et al. (2002) noted that the development of information and communication technology (ICT) curtailed exploitation of poor farmers by a middleman and enabled the farmers to participate directly in the market. Direct participation in the market raises the farmers' bargaining power and standard of living. Sreedevi and Meena (2011) argued that the existence of ICT in the banking industry provided numerous advantages such as easy access to banking prod-

ucts and services, insurance services, financial education, adequate credit, and financial information or advice.

\section{Contribution of this study}

Some studies (Andrianaivo and Kpodar 2012; Mago and Chitokwindo 2014; Thulani et al. 2014) conducted in African countries focused on the use of mobile phones for easy 
access to financial products and services. However, to the best of our knowledge, there is no literature regarding SAARC countries that can demonstrate the effect of both mobile phones and the Internet on financial inclusion. This study aims to add some value to the existing literature in that regard.

Financial inclusion is a multidimensional concept that includes various factors affecting accessibility and usability of financial products and services. Most researchers have used just a few dimensions to measure the degree of financial inclusion, such as the number of commercial bank branches per 100,000 adult population, the number of ATMs in $1000 \mathrm{~km}^{2}$, and the measure of credit and deposits as a percentage of gross domestic product (GDP). These financial indicators, however, do not provide a complete measurement of financial inclusion. Very few studies have created an index of financial inclusion using different financial dimensions and methodologies (Chakravarty and Pal 2013; Chattopadhyay 2011; Sarma 2015; Lenka and Bairwa 2016).

To avoid this deficiency, in our research, we used a financial inclusion index computed by applying principal component analysis (PCA) using different types of financial proxy variables (e.g., loans, deposits, bank branches per 100,000 populations, numbers of ATMs per 100,000 populations, bank branches per $1000 \mathrm{~km}^{2}$ area, ATMs per $1000 \mathrm{~km}^{2}$ area) to measure financial inclusion in SAARC countries. Moreover, we extended the present study to explore both the impact and causality of mobile and Internet services on financial inclusion in SAARC countries.

\section{Model specification, data, and methodology Model specification and data}

Throughout our literature review, we could not find any empirical study investigating the impact of mobile phones and Internet services on financial inclusion in the SAARC countries. As shown earlier, the use of mobile phone and Internet services has increased rapidly in the SAARC countries during the past decade. Their use has helped to enhance financial inclusion largely. In this study, we took mobile and Internet usages explanatory variables for analyzing their effect of these on financial inclusion. Thus, we proposed the following empirical model:

$$
F I_{i t}=\alpha_{0}+\beta_{1} M O B_{i t}+\beta_{2} I N T_{i t}+\beta_{3} C t r l_{i t}+\mu_{i t},
$$

where $F I$ is the index of financial inclusion, $M O B$ denotes mobile phone penetration (mobile cellular subscriptions per 100 people), and INT denotes Internet penetration (Internet users per 100 people). Ctrl denotes a vector of control variables of financial inclusion, $Y$ denotes income level (proxies by GDP per capita), RPOP denotes rural population (as a percent of total population), EDU denotes education level (proxied by total secondary school enrollment of both sexes), UEMP denotes total unemployment (percent of total labor force), and $\mu_{i t}$ is an error term. Though there is a high correlation between these two variables like mobile phone and the Internet, we regress separately with financial inclusion along with same control variables. The functional forms of both models are specified as follows: 


$$
\begin{aligned}
& F I_{i t}=\alpha_{0}+\beta_{1} \text { mob }_{i t}+\beta_{2} \operatorname{Ctrl}_{i t}+\mu_{\mathrm{it},} \\
& F I_{i t}=\alpha_{0}+\beta_{3} I_{i t}+\beta_{4} C t r l_{i t}+\mu_{i t} .
\end{aligned}
$$

In eq. (2), mobile penetration and other control variables are used as independent variables with financial inclusion. Similarly, in eq. (3) Internet penetration and the same control variables are used as independent variables with financial inclusion.

For this study, we analyzed annual data for the period from 2004 to 2014 of all the SAARC countries. We used the scale of bank accounts per 100,000 adults to measure the density of commercial bank branches, and we used the number of ATMs per $1000 \mathrm{~km}^{2}$ as the measure the density of ATMs. In addition, we took the volume of outstanding credit and deposits in the private sector as a proportion of country's GDP to measure the usage dimension of financial inclusion. We gathered the necessary data from various data sources, including the International Financial Statistics published by IMF and the Financial Access Survey from the International Monetary Fund. We collected the data for other control variables, such as per capita GDP, rural population, education, and unemployment, from the World Development Indicators (WDI) of the World Bank database.

\section{Explanation of variables}

Per capita GDP

Per capita GDP is an important ingredient determining the degree of financial inclusion (Sarma and Pais 2011). People who earn a high income are more likely to be included in the formal financial system than low-income people. An increase in income has a positive and significant effect on saving and credit (Kumar 2011). Per capita income is the major constituent influencing the penetration of banking services (RBI 2015).

\section{Rural population}

Generally, rural people are excluded from the formal financial system to a greater extent than urban residents. In rural areas, low levels of financial education, less availability of bank branches, low income, fewer employment opportunities, and other socioeconomic factors prevent local residents from participating more fully in banking services. States bearing more rural population have a relatively low rate of financial inclusion (RBI 2015).

\section{Education (secondary)}

An individual's education level is a demand-side factor that often determines the involvement of that individual in the formal financial system. A low level of financial education leads to lack of knowledge about saving and credit options, as well as little or no information regarding the financial market. Secondary education can raise awareness among the younger generation about the different uses and benefits of mobile banking. Education also enables a consumer to understand basic financial concepts such as deposit accounts, credit accounts, various insurance schemes, pension products, credit facilities, profitable investment choices, and many more. In today's world, it is impossible to understand the modern and complex financial system without understanding basic economics and finance (Sukumaran 2015). Education has significant positive externalities on society. Therefore, the rise of secondary education spreads awareness about the advantages of financial inclusion in society. This financial awareness among consumers 
encourages them to avoid the informal source of financial services and protects them from unfair financial practices.

Unemployment (\% of Total labor force)

Employment is considered an important factor affecting financial inclusion. First, an individual's increased employment (formal or informal) generally is accompanied by a growth in income that can lead to participation in the formal financial system. Second, formal employment automatically links the employee with the formal financial system via wage transactions and other benefits routed through banks and other services. Improved employment encourages individuals to be more active, aware, and interested in a financial activity at a bank, which ultimately raises the speed of financial inclusion (Kumar 2011). In contrast, increased unemployment can lead to less initiative on the part of individuals to participate in the formal financial system. People who are unemployed, or who have only irregular and insecure income, are less likely to participate in any formal financial system (Sarma and Pais 2011).

\section{Results and discussion}

\section{Result of PCA}

This study applied PCA to create a single index composed of the six selected indicators of financial inclusion. According to this procedure, the $j$ th factor index can be expressed as follows:

$$
\mathrm{FIj}=W_{J 1} X_{1}+W_{J 2} X_{2}+W_{J 3} X_{3}+\ldots+W_{J P} X_{P},
$$

where $\mathrm{FI}_{j}$ is the financial inclusion index, $W_{j}$ is the weight on factor score coefficient, $X$ is the respective original value of the components, and $P$ is the number of variables in the equation. To construct the composite financial inclusion index, we used three dimensions, in which case each dimension consisted of two factors. For this study, the constructed financial inclusion index was composed of three dimensions and six factors. The three dimensions are geographic penetration, demographic penetration, and banking penetration (Lenka and Bairwa 2016).

\section{Dimension 1 (geographic penetration)}

In this index, we used the number of commercial bank branches and the number of ATMs per $1000 \mathrm{~km}^{2}$ to measure the geographic dimensions of financial inclusion in SAARC countries.

\section{Dimension 2 (demographic penetration)}

We applied the data reflecting the number of commercial bank branches and number of ATMs per 100,000 adults to measure the demographic dimensions of financial inclusion.

\section{Dimension 3 (banking usage penetration)}

In the present index, we used data related to the volume of outstanding credit and deposits in the private sector as a percentage of GDP to measure this dimension.

This paper used ATM and bank branches data to construct the financial inclusion index in the SAARC countries. The use of ATM and bank branches data in the context of geography and demography showed the density of ATM and bank branches in a locality. The presence of ATM and bank branches in a locality showed the availability of ATM facilities and bank branches in the locality and among the people. The accessibility of ATMs and bank branches reduces transaction costs and saves customers' time, 
which ultimately encourages them to conduct more financial transactions with the banks. Furthermore, for the construction of financial inclusion in SAARC countries, the study used the data related to credit and deposits as a percentage of GDP, showing the usability of banking services among the people.

For this research, we used six different indicators for the financial inclusion index in SAARC countries. As discussed earlier, however, financial inclusion is a multidimensional concept that includes a large number of other financial inclusion indicators. To strengthen the financial inclusion index, other indicators may be included, such as the number of deposit and credit accounts with scheduled commercial banks per 1000 adult population, the ratio of bank employees per bank branches (Lenka and Sharma 2017), the amount of deposits and credit with microfinance institutions (MFIs), the number of MFIs branches per $1000 \mathrm{~km}^{2}$ and 100,000 population, the amount of credit obtained by small and medium enterprises, and so on. Because of the lack of availability of much of the previously cited data in the context of SAARC countries, this paper used only six different indicators to construct the financial inclusion index in SAARC countries.

Using the PCA method, we calculated the eigenvalues of all six factors included in the three dimensions used in this study. Among all, the highest eigen value retained more standardized variance and a value greater than the one considered for the analysis. Next, we took the factor score (weights) calculated by the PCA, multiplied it by the respective variable, and then added them all to get the final index. In this process, we evaluated each country's financial inclusion index. The index for each is shown in Table 3.

As Table 3 shows, Maldives ranked first in the overall financial inclusion index, followed by Bangladesh and India, whereas both Pakistan and Afghanistan placed in the bottom positions among the SAARC countries. Countries like Nepal, Bhutan, and Sri Lanka, however, placed in the middle segment of financially inclusive countries, meaning that these countries had a modest level of financial inclusion that was neither the highest nor the lowest.

Table 4 demonstrates the individual nature of both the dependent and independent variables. On average, SAARC countries grew by $23.6 \%$ during the specified period,

Table 3 Estimation of financial inclusion index in SAARC countries (2004-2014)

\begin{tabular}{lllllllll}
\hline Year & Afghanistan & Bangladesh & Bhutan & India & Maldives & Nepal & Pakistan & Sri Lanka \\
\hline 2004 & 0.898 & 21.017 & 12.277 & 19.274 & 38.691 & 14.137 & 0.450 & 7.710 \\
2005 & 1.625 & 21.885 & 11.505 & 20.172 & 42.748 & 14.404 & 0.386 & 7.852 \\
2006 & 2.515 & 22.875 & 12.586 & 21.435 & 46.466 & 14.773 & 1.120 & 10.908 \\
2007 & 3.302 & 23.326 & 12.950 & 23.229 & 70.177 & 16.556 & 1.283 & 12.262 \\
2008 & 4.776 & 24.684 & 15.164 & 25.740 & 71.754 & 18.596 & 2.555 & 15.316 \\
2009 & 5.675 & 26.588 & 17.697 & 27.403 & 75.475 & 20.629 & 3.091 & 17.142 \\
2010 & 5.749 & 29.632 & 20.203 & 28.723 & 76.668 & 20.031 & 4.783 & 18.604 \\
2011 & 5.077 & 33.588 & 22.091 & 31.262 & 78.590 & 20.625 & 5.609 & 20.836 \\
2012 & 4.609 & 37.854 & 19.362 & 33.750 & 87.256 & 23.871 & 5.726 & 22.304 \\
2013 & 4.687 & 39.016 & 22.988 & 36.069 & 92.671 & 24.215 & 7.035 & 23.362 \\
2014 & 4.715 & 44.505 & 24.203 & 40.994 & 94.869 & 25.308 & 8.702 & 24.158 \\
\hline
\end{tabular}

Source: Calculated by authors 
Table 4 Summery statistics

\begin{tabular}{llllll}
\hline Variables & Obs. & Mean & SD & Min & Max \\
\hline FI & 88 & 23.606 & 21.554 & 0.386 & 94.869 \\
MOB & 88 & 54.284 & 42.765 & 0.469 & 189.383 \\
INT & 88 & 9.872 & 10.224 & 0.106 & 49.280 \\
INCOME & 88 & 4.478 & 4.055 & 11.167 & 18.002 \\
RPOP & 88 & 71.439 & 7.913 & 55.506 & 85.129 \\
UEMP & 88 & 5.774 & 3.159 & 2.000 & 14.400 \\
EDU & 88 & 1.641 & 3.382 & 2.887 & 11.900 \\
\hline
\end{tabular}

Source: Calculated by authors

while average mobile and Internet penetration stood at $54.2 \%$ and $9.8 \%$, respectively. These findings show that Internet penetration was far behind compared with mobile penetration in SAARC countries during 2004-2014. Similarly, average income, rural population, unemployment, and education levels were 4.4, 71.4, 5.7, and 1.6, respectively.

Table 5 shows the correlations between the variables. As demonstrated, mobile phone, Internet, income, and education were positively associated with financial inclusion, whereas rural population and unemployment were negatively correlated with financial inclusion. There was a high correlation (0.984) between mobile and Internet services in all the SAARC countries. Therefore, we used a separate regression analysis for mobile and Internet services for financial inclusion.

Before running causality and regression analyses to examine the panel data, we used the (Im, Pesaran and Shin (IPS) panel unit root test developed by Im et al. (2003) to confirm the stationarity of the series. The result of the IPS test suggested that financial inclusion (FI) constructed using PCA, mobile users (MOB), and Internet users (INT) are stationary in their first difference but not in their level form (see Table 6). Hence, we estimated the long-run relationship by using the Pedroni panel co-integration method. The results of the co-integration test are reported in Table 7 . We employed panel co-integration with two different types of specifications (without trend and with the trend) of the financial inclusion index with mobile and Internet users to observe whether or not the variables included in the analysis had long run co-movement.

The Pedroni panel co-integration test showed that the majority reported (in Table 7) among the above seven tests (four within the group and three between group) of the cointegration are significant either at $5 \%$ or $1 \%$ level of significance. First, we tested both MOB

Table 5 Correlation matrix

\begin{tabular}{llllllll}
\hline Variables & FI & MOB & INT & Y & RPOP & UEMP & EDU \\
\hline FI & 1.000 & & & & & & \\
MOB & 0.577 & 1.000 & & & & & \\
INT & 0.520 & 0.984 & 1.000 & & & & \\
Y & 0.013 & 0.099 & 0.084 & 1.000 & & & \\
RPOP & -0.461 & -0.470 & -0.508 & 0.074 & 1.000 & & \\
UEMP & -0.457 & -0.469 & -0.301 & -0.036 & -0.354 & 1.000 & \\
EDU & 0.065 & 0.094 & 0.098 & 0.138 & -0.120 & -0.267 & 1.000 \\
\hline
\end{tabular}

Source: Calculated by authors 
Table 6 IPS panel unit root test result

\begin{tabular}{lllll}
\hline Variables & Period & $\begin{array}{l}\text { Number } \\
\text { of } \\
\text { Countries }\end{array}$ & & \multicolumn{2}{l}{ Test statistics } & Level & 1st difference \\
\hline Financial inclusion (FI) & $2004-2014$ & 8 & 3.576 & $-2.077^{\text {a }}$ \\
Mobile users (MOB) & $2004-2014$ & 8 & 2.226 & $-2.898^{\text {a }}$ \\
Internet users (INT) & $2004-2014$ & 8 & 1.368 & $-2.353^{\text {a }}$ \\
\hline
\end{tabular}

${ }_{\text {andicates significance at the } 1 \% \text { level }}$

and INT with FI. Most of the test results were insignificant, indicating no co-integration relationship. However, when we tested each variable individually with FI, the majority of tests showed that MOB and INT were significant, clearly indicating that MOB and INT have a co-integration relationship with FI. Therefore, we can infer that an increase in MOB and INT are important sources for enhancing financial inclusion in SAARC countries.

Next, we performed a separate regression for MOB and INT with financial inclusion along with some control variables. Moreover, we used 1st difference variables FI, MOB, and INT in place of the actual variables because these variables were stationary in the 1st difference rather than in their level form (see Table 6). If we had conducted the regression analysis with the variables in level form, the results might have been spurious.

From Table 8, based on model I (Fixed Effect Model - FEM), we concluded that mobile penetration (MOB), the proxy for mobile phone subscribers in SAARC countries, was positively associated with financial inclusion: a $1 \%$ increase in mobile penetration increased the level of financial inclusion by $0.131 \%$ in the SAARC countries during 2004-2014. Along with mobile penetration, the income of the people (Y) was positively associated with financial inclusion: a $1 \%$ increase in the $\mathrm{Y}$ of the people led to an $0.116 \%$ increase in financial inclusion. Similarly, rural population (RPOP) and unemployment (UEMP) were negatively associated with financial inclusion in the SAARC countries: a $1 \%$ increase in rural population led to a $1.615 \%$ decrease in financial inclusion, and a $1 \%$ increase in UEMP led to a $0.671 \%$ decrease in financial inclusion. Education (EDU) and financial inclusion in the SAARC countries were positively associated with each other, but statistically insignificant.

From Table 8, we note that model II (Random Effect Model - REM) demonstrated a positive relationship between $\mathrm{MOB}$ and financial inclusion. The coefficient showed that a $1 \%$ increase in MOB led to an increase of $0.192 \%$ in financial inclusion in SAARC countries from 2004 to 2014. Similarly, RPOP and UEMP were negatively associated with financial inclusion. The coefficient showed that a $1 \%$ increase in RPOP and UEMP could decrease financial inclusion by $1.302 \%$ and $0.517 \%$, respectively. Last, EDU and financial inclusion were positively related to each other, but statistically insignificant. After assessing the FE and RE models, we used the Hausman test to check best-fitted models in this study. In this study, the Hausman test indicated that the probability value was $0.912 \%$, which was more than $5 \%$, so we could not reject the null hypothesis in this case. Therefore, the FE model provided a better fit than the RE model in our analysis.

Similarly, to ascertain the effect of Internet usage on financial inclusion in SAARC countries, we performed a regression using the financial inclusion index with the number of Internet subscribers per 100 people, and using other control variables (e.g., Y, RPOP, UEMP, and EDU), as in the previous regressions. The results of model I (Fixed 
Table 7 Pedroni panel co-integration test result

\begin{tabular}{|c|c|c|c|c|c|c|}
\hline \multirow[t]{2}{*}{ Test } & \multicolumn{2}{|l|}{$F I, M O B$, and INT } & \multicolumn{2}{|l|}{$\mathrm{Fl}$ and $M O B$} & \multicolumn{2}{|l|}{ Fl and INT } \\
\hline & Without Trend & With Trend & Without Trend & With Trend & Without Trend & With Trend \\
\hline Panel v-stat & 0.988 & -1.004 & $6.157^{c}$ & $4.281^{c}$ & 0.608 & $-1.961^{b}$ \\
\hline Panel rho-stat & -0.794 & 0.280 & $-2.900^{c}$ & 0.141 & -0.747 & 1.082 \\
\hline Panel PP-stat & $-3.902^{c}$ & $-4.983^{c}$ & $-4.657^{c}$ & $-2.745^{c}$ & $-2.150^{b}$ & $-2.764^{\mathrm{C}}$ \\
\hline Panel ADF-stat & $-4.062^{c}$ & $-5.000^{c}$ & $-5.380^{c}$ & $-2.991^{\mathrm{c}}$ & $-2.723^{c}$ & $-2.858^{\mathrm{b}}$ \\
\hline Group rho-stat & 1.900 & 2.490 & 0.835 & 1.765 & 1.835 & 2.030 \\
\hline Group PP-stat & $-1.410^{\mathrm{a}}$ & -1.576 & $-1.451^{a}$ & $-3.648^{c}$ & 0.612 & $-3.223^{c}$ \\
\hline Group ADF-stat & $-1.820^{\mathrm{b}}$ & $-3.441^{c}$ & $-2.056^{\mathrm{b}}$ & $-3.930^{c}$ & -1.268 & $-2.714^{c}$ \\
\hline
\end{tabular}

${ }^{\mathrm{a}}{ }^{\mathrm{b}}$, and ${ }^{\mathrm{c}}$ indicate significance at $10 \%, 5 \%$, and $1 \%$, respectively

Effect Model - FEM) showed that Internet usage and financial inclusion are positively related to each other: a $1 \%$ increase in Internet use increased the level of financial inclusion $0.319 \%$ in the SAARC countries from 2004 to 2014. Except for Internet services, other control variables, such as RPOP and UEMP, were negatively associated with financial inclusion, whereas $\mathrm{Y}$ and EDU levels were positively associated with financial inclusion (see Table 9). The coefficient showed that a $1 \%$ increase in RPOP and UEMP led to a decrease in financial inclusion of $1.113 \%$ and $0.265 \%$, respectively. However, a $1 \%$ increase in EDU led to a $0.399 \%$ change in financial inclusion, and Y was positively associated with financial inclusion, but statistically insignificant.

To determine the robustness of these results, our study used model II (Random Effect Model - REM). The empirical results for this model indicated that financial inclusion was positively linked with Internet services, as in model I: a $1 \%$ change in Internet use led to a $0.416 \%$ increase in financial inclusion. Moreover, other control variables

Table 8 Regression on mobile phone and financial inclusion in SAARC countries

\begin{tabular}{llll}
\hline Variable & Model I & Model II & Model III \\
\hline MOB & $0.131^{\mathrm{b}}$ & $0.192^{\mathrm{a}}$ & $0.250^{\mathrm{a}}$ \\
Y & $(2.29)$ & $(3.49)$ & $(3.98)$ \\
& $0.116^{\mathrm{b}}$ & 0.034 & $0.235^{\mathrm{c}}$ \\
RPOP & $(2.37)$ & $(0.33)$ & $(1.92)$ \\
& $-1.615^{\mathrm{a}}$ & $-1.302^{\mathrm{a}}$ & $-0.178^{\mathrm{a}}$ \\
UEMP & $(-6.73)$ & $(-6.03)$ & $(-3.53)$ \\
& $-0.671^{\mathrm{a}}$ & $-0.517^{\mathrm{a}}$ & $-0.729^{\mathrm{a}}$ \\
EDU & $(-3.92)$ & $(-3.15)$ & $(3.91)$ \\
& 0.107 & 0.296 & $0.236^{\mathrm{a}}$ \\
Model & $(0.31)$ & $(0.63)$ & $(3.31)$ \\
Colinearity & FEM & $\mathrm{REM}$ & PCSE \\
Heteroscedasticity & 0.791 & & 80 \\
Observation & 639.2 & 80 & 0.092 \\
Prob. & 80 & 0.064 & \\
\hline
\end{tabular}

Source: Calculated by authors

Note: The bracket value of first, second, and third model indicates t-value, z-value, and again z-value, respectively a Level of significance at $1 \%$

bevel of significance at $5 \%$

'Level of significance at $10 \%$ 
Table 9 Regression on Internet services and financial inclusion in SAARC countries

\begin{tabular}{llll}
\hline Variable & Model I & Model II & Model III \\
\hline INT & $0.319^{\mathrm{b}}$ & $0.416^{\mathrm{a}}$ & $0.512^{\mathrm{a}}$ \\
& $(2.51)$ & $(3.27)$ & $(3.65)$ \\
Y & 0.035 & $0.031^{\mathrm{b}}$ & $0.123^{\mathrm{b}}$ \\
& $(0.36)$ & $(2.32)$ & $(2.58)$ \\
RPOP & $-1.113^{\mathrm{a}}$ & $-1.239^{\mathrm{a}}$ & $-0.917^{\mathrm{a}}$ \\
& $(-6.68)$ & $(-6.42)$ & $(-5.27)$ \\
UEMP & $-0.265^{\mathrm{a}}$ & $-0.968^{\mathrm{a}}$ & $-0.189^{\mathrm{a}}$ \\
& $(-3.44)$ & $(-3.07)$ & $(-9.10)$ \\
EDU & $0.399^{\mathrm{c}}$ & $0.192^{\mathrm{c}}$ & $0.342^{\mathrm{a}}$ \\
& $(1.99)$ & $(1.94)$ & $(9.97)$ \\
Model & FEM & $\mathrm{REM}$ & PCSE \\
Colinearity & 0.786 & & 80 \\
Heteroscedasticity & 585.3 & & 0.093 \\
Observation & 80 & 0.072 & \\
Prob. & 0.083 & & \\
\hline
\end{tabular}

Source: Calculated by authors

Note: The bracket value of first, second, and third model indicates t-value, z-value, and again z-value, respectively

a Level of significance at $1 \%$

b Level of significance at $5 \%$

'Level of significance at $10 \%$

gave the same results as model I. Last, we used the Hausman test to check the best-fitted model in this study. The result of the Hausman test showed that the probability value was $0.786 \%$, which was more than $5 \%$, so we could not reject the null hypothesis in this case. Thus, the FE model was the best model, rather than the RE model.

To address the problem of heteroscedasticity and autocorrelation, we used the Modified Wald test and the Wooldridge test. The results showed that heteroscedasticity and autocorrelation were present in the model II. To overcome the previously cited problems, this study used model III (Panel Correction Standard Errors - PCSEs) in eqs. (2) and (3). Our findings showed that use of both mobile phones and the Internet are statistically significant, and they have a positive impact on financial inclusion in the SAARC countries.

Once the co-integration was established (see Table 7), then the issue that needed to be addressed was the direction of causality. We used the panel Granger causality test to estimate the causality between variables. The results of the panel Granger test indicated that there was a unidirectional relationship between MOB and INT with FI (see Table 10). Moreover, MOB had a unidirectional relationship with INT. The results clearly showed that the direction of causality was only from both MOB and INT toward FI, but not vice-versa, indicating that an increase in mobile and Internet users extends financial inclusion in the SAARC countries.

\section{Conclusion and policy implications}

Considering the financial infrastructure gap in SAARC countries, this study investigated whether the expansion of mobile and Internet services fostered financial inclusion in that region based on sample data from 2004 to 2014. Using PCA, we proposed a multidimensional 
Table 10 Panel Granger causality test result

\begin{tabular}{llll}
\hline $\begin{array}{l}\text { Dependent } \\
\text { Variables }\end{array}$ & \multicolumn{2}{l}{ Sources of causation } \\
\cline { 2 - 4 } & \multicolumn{2}{l}{ Independent variables } & INT \\
\cline { 2 - 4 } & $\mathrm{FI}$ & $3.061(0.025)^{\mathrm{a}}$ & $3.794(0.007)^{\mathrm{b}}$ \\
$\mathrm{FI}$ & $1.074(0.729)$ & & $1.081(0.135)$ \\
$\mathrm{MOB}$ & $1.857(0.972)$ & $2.190(0.049)^{\mathrm{a}}$ & \\
\hline
\end{tabular}

Note: ${ }^{\mathrm{a}}$ and ${ }^{\mathrm{b}}$ indicate significance at the $5 \%$ and $1 \%$ level, respectively

financial inclusion index that measured information about financial access in the SAARC countries. Our findings indicated that the growth of mobile and Internet use was positively associated with financial inclusion and which extended financial access in the SAARC countries. Furthermore, our empirical investigation showed that both income and education levels are positively associated with financial inclusion, whereas the size of the rural population and unemployment were negatively associated with financial inclusion in the SAARC countries. Finally, the study also found that there is a unidirectional causal flow from the increased number of both mobile and Internet users to the expansion of financial inclusion.

Considering the evidence that expansion of mobile and Internet use enhances financial inclusion in all SAARC countries, there are two important goals for the governments and financial institutions in that region. First, access to wireless communications and the Internet should be expanded to include all economic groups. Second, secure wireless financial products and services should be made easily accessible and widely available. These steps will have a positive impact on financial inclusion, which in turn can promote economic development.

We recognize that the present study has some limitations. It is difficult to identify the causal effect of both mobile and Internet usage on financial inclusion without an appropriate instrument, such as an exogenous shock to the adoption and use of mobile phones and the Internet. Given the absence of data that could be provided by such an instrument, the results of this study may indicate the evidence of causality only, without addressing their endogenous nature. In our research working with the available data, it was impossible to determine causality rigorously. Consequently, our future research may consider these external shocks while investigating the causal relationships. Further research is required in this area in SAARC countries, as well as in other developing countries.

\section{Appendix}

Table 11 Variables and Description

\begin{tabular}{lll}
\hline Variables & Measurement & Symbol \\
\hline Financial inclusion & Index of financial inclusion & $\mathrm{FI}$ \\
Mobile penetration & Mobile cellular subscriptions per 100 people & MOB \\
Internet penetration & Internet users per 100 people & INT \\
Income & GDP per capita & Y \\
Rural population & Rural population as (\% of total population) & RPOP \\
Unemployment & Total unemployment (\% of total labor force) & UEMP \\
Education & Total secondary school enrollment of both sexes & EDU
\end{tabular}




\section{Acknowledgements}

We are grateful to Dr. Ruchi Sharma, Indian Institute of Technology Indore for her regular support and suggestions to complete this study easily. We also express our gratitude towards anonymous referees for giving their valuable comments. The authors take all the responsibilities for all the errors and omissions (if there are any). We also thank to our parent organization, the Indian Institute of Technology Indore, India, which facilitated us with all the required resources for this study.

\section{Funding}

We would like to express our gratitude to the Ministry of Human Resource Development, Govt. of India, for providing us financial support during this study period.

\section{Author's contributions}

SKL carried out design of the research, supervised and analysed the data in the study. RB prepared the manuscript. Both authors read and approved the final manuscript.

\section{Competing interest}

The authors declare that they have no competing interests.

\section{Publisher's Note}

Springer Nature remains neutral with regard to jurisdictional claims in published maps and institutional affiliations.

\section{Author details}

${ }^{1}$ Consumer Unity \& Trust Society (CUTS) International (a global independent non-profit economic policy research and advocacy organization), D-217, Bhaskar Marg, Bani Park, Jaipur, Rajasthan -302016, India. ${ }^{2}$ School of Humanities and Social Sciences, Indian Institute of Technology, Simrol Campus, Khandwa Road, Indore 453552, India.

\section{Received: 26 August 2016 Accepted: 20 February 2018}

Published online: 08 March 2018

\section{References}

Abraham R (2007) Mobile phones and economic development: evidence from the fishing industry in India. Inf Technol Int Dev 4(1):5-17

Aker JC (2010) Information from markets near and far: mobile phones and agricultural Markets in Niger. American Economic Journal: Applied Economics 2(3):46-59

Aker JC, Mbiti IM (2010) Mobile phones and economic development in Africa. J Econ Perspect 24(3):207-232

Alam MZ, Patwary MM, Rahim MA (2013) Mobile money system: the Bangladesh experience. International Journal of Scientific and Research Publications 3(10):1-5

Andrianaivo M, Kpodar K (2012) Mobile phones, financial inclusion, and growth. Review of Economics and Institutions 3(2):30

Burgess R, Pande R (2005) Do rural banks matter? Evidence from the Indian social banking experiment. Am Econ Rev 95(3):780-795

Chakravarty SR, Pal R (2013) Financial inclusion in India: an axiomatic approach. J Policy Model 35(5):813-837

Chattopadhyay SK (2011) Financial Inclusion in India: A case-study of West Bengal. RBI Working Paper Series-8:1-27

Cherotich KM, Sang W, Shisa A, Mutung'u C (2013) Financial innovations and performance of commercial banks in Kenya. International Journal of Economics. Commerce and Management III(5):1242-1265

Eggleston K, Jensen R, Zeckhauser R (2002) Information and communicationTechnologies, Markets and economic development. Tufts Working paper:1-25

Ghosh S (2016) Does mobile telephony spur growth? Evidence from Indian states. Telecommun Policy 40(10-11): 1020-1031

Hirashima S, Oda H, Tsujita Y (2011) Introduction: Inclusiveness in India — A Challenging Strategy for Growth and Equality. Inclusiveness in India chapter-3:1-32

Klein MU and Mayer C (2011) Mobile banking and financial inclusion: The regulatory lessons. World Bank Policy Research Working Paper Serie, 5664

Kumar N (2011) Financial Inclusion and its determinants: Evidence from the state level empirical analysis in India. In: Proceedings of the 13th Annual Conference on Money and Finance in the Indian Economy. Indira Gandhi Institute of Development Research, Mumbai, India

Kusimba S, Chaggar H, Gross E, Kunyu G (2013) Social networks of mobile money in Kenya. IMTFI Working Paper

Lenka SK, Bairwa AK (2016) Does financial inclusion affect monetary policy in SAARC countries? Cogent Economics \& Finance 4(1):1-8

Lenka SK, Sharma R (2017) Does financial inclusion spur economic growth in India? The Journal of Developing Areas 51(3):215-228

Liao Z, Cheung MT (2002) Internet-based e-banking and consumer attitudes: an empirical study. Information \& Management 39(4):283-295

Mago S, Chitokwindo S (2014) The impact of mobile banking on financial inclusion in Zimbabwe: a case for Masvingo Province. Mediterranean Journal of Social Sciences 5(9):22

Ouma SA, Odongo TM, Were M (2017) Mobile financial services and financial inclusion: is it a boon for savings mobilization? Review of Development Finance 7(1):29-35

Planning Commission, Government of India (2009) A hundred small steps: report of the committee on financial sector reforms, New Delhi 
Rajeev M, Vani BP (2017) Financial exclusion of the poor: global experiences. SpringerBriefs in Economics Financial Access of the Urban Poor in India 2017:15-37

Reserve Bank of India (2015) Report of the Committee on Medium-term Path on Financial Inclusion

Sangmi M (2013) Financial inclusion strategies in developing countries with special reference to India. Journal of public Administration, Finance, and Law 4:97-107

Sarma M (2015) Measuring financial inclusion. Econ Bull 35(1):604-611

Sarma M, Pais J (2011) Financial inclusion and development. J Int Dev 23:613-628

Siddik M, Sun G, Kabiraj S, Joghee S, Yanjuan C (2017) Impacts of capital structure on performance of banks in a developing economy: evidence from Bangladesh. International Journal of Financial Studies 5(2):13

Sreedevi V, Meena K (2011) ICT and financial inclusion. International Journal of BusinessManagement, Economics and Information Technology 3(2):331-334

Sukumaran K (2015) Financial access: inclusion and literacy. Annual Research Journal of Symbiosis Centre for Management Studies 3(1):188-207

Sultana B, Khan MMR (2016) Are mobile financial services promoting financial inclusion in Bangladesh? An assessment study, Working paper series: WP No 1623. Research Department, Bangladesh Bank

Thulani M, Chitakunye P, Chummun BZ (2014) Mobile money as a strategy for financial inclusion in rural communities. Mediterranean Journal of Social Sciences 5(25):216-224

Vadavadagi PK, Allagi RG (2014) Financial inclusion through mobile banking a case of India. EPRA international journal of economic and business review 2(10):108-114

Submit your manuscript to a SpringerOpen ${ }^{\circ}$ journal and benefit from:

- Convenient online submission

- Rigorous peer review

Open access: articles freely available online

- High visibility within the field

Retaining the copyright to your article

Submit your next manuscript at $\gg$ springeropen.com 